\title{
Effect of Saline Stress and Calcium Nitrate on Lettuce Grown on Coconut Fiber
}

\author{
Francisco de A. de Oliveira ${ }^{1}$, Isabelly C. da S. Marques ${ }^{2}$, Ana Jacqueline de Oliveira Targino ${ }^{1}$, \\ Carla J. X. Cordeiro ${ }^{1}$, Mychelle K. T. de Oliveira ${ }^{1}$, Lúcia R. de L. Régis ${ }^{1}$, \\ Paula A. de A. Costa $^{1} \&$ Rafaelle da S. Freitas ${ }^{1}$ \\ ${ }^{1}$ Universidade Federal Rural do Semi-Árido, Mossoró, RN, Brazil \\ ${ }^{2}$ Universidade Estadual Paulista, Botucatu, SP, Brazil \\ Correspondence: Francisco de A. de Oliveira, Universidade Federal Rural do Semi-Árido, Mossoró, RN, Brazil. \\ E-mail: thikaoamigao@ufersa.edu.br
}

Received: April 2, 2018

doi:10.5539/jas.v10n11p259

\author{
Accepted: July 6, $2018 \quad$ Online Published: October 15, 2018 \\ URL: https://doi.org/10.5539/jas.v10n11p259
}

\begin{abstract}
This study aimed to evaluate the use of saline solutions enriched with calcium nitrate in the production of lettuce grown in coconut fiber. The experiment was carried out from July to August 2017 in a greenhouse, at the Federal Rural University of the Semi-Arid Region (UFERSA), Mossoró-RN, Brazil. A randomized block design was used, in $2 \times 5$ factorial scheme, with three replicates. Treatments resulted from the combination of two lettuce cultivars [Elba (Curly) and Irene (Crisphead)] and five nutrient solutions (S1- standard nutrient solution; S2-S1 + $\mathrm{NaCl}\left(28.48 \mathrm{mmol} \mathrm{L}{ }^{-1}\right) ; \mathrm{S} 3-\mathrm{S} 2+\mathrm{Ca}\left(\mathrm{NO}_{3}\right)_{2}\left(6.89 \mathrm{mmol} \mathrm{L}^{-1}\right) ; \mathrm{S} 4-\mathrm{S} 2+\mathrm{Ca}\left(\mathrm{NO}_{3}\right)_{2}\left(9.15 \mathrm{mmol} \mathrm{L}^{-1}\right) ; \mathrm{S} 5-\mathrm{S} 2+$ $\left.\mathrm{Ca}\left(\mathrm{NO}_{3}\right)_{2}\left(11.43 \mathrm{mmol} \mathrm{L}{ }^{-1}\right)\right]$. Plants were harvest 30 days after transplantation and the following variables were analyzed: head diameter, stem diameter, number of leaves, fresh weight, dry weight, leaf area, specific leaf area and leaf succulence. The cv. Irene (Crisphead) is more tolerant to nutrient solution salinity compared with the cv. Elba (Curly). Nutrient solutions enriched with 50 and $100 \%$ of $\mathrm{Ca}\left(\mathrm{NO}_{3}\right)_{2}$ promoted better performance of the cultivars Elba and Irene, respectively, fertigated with saline nutrient solution.
\end{abstract}

Keywords: Lactuca sativa, hydroponic cultivation, salinity, soilless cultivation

\section{Introduction}

Lettuce (Lactuca sativa L.), belonging to the Asteraceae family, is the main leafy vegetable produced and consumed in the world, especially in the form of salads (Sala \& Costa, 2012). In addition, it is the most cultivated and adapted vegetable to the protected system, especially hydroponics, standing out for its short cycle, which allows faster return of the invested capital.

Lettuce is a crop classified as sensitive to salinity, exhibiting a threshold of $1.3 \mathrm{dS} \mathrm{m}^{-1}$ in the saturation extract and $0.9 \mathrm{dS} \mathrm{m}^{-1}$ in the irrigation water (Maas \& Hoffman, 1977). Nevertheless, tolerance to salinity is variable among varieties and, even within a varieties, between growth stages. In each growth stage, tolerance to salinity is controlled by more than one gene and highly influenced by environmental factors (T. J. Flowers \& S. A. Flowers, 2005; Munns, 2005; Parida \& Das, 2005).

The use of saline water to prepare nutrient solutions is a great challenge for researchers because, depending on the studied species, it may negatively affect the commercial yield of the crops. In lettuce in a floating system, Neocleous et al. (2014) observed reduction in fresh weight due to the lower absorption of water and nutrients, decrease in photosynthesis and in the restriction of $\mathrm{CO}_{2}$ availability.

However, yield reduction can be compensated, at least partially, by the increase in the contents of anthocyanins in red lettuces, as well as by the improvement of freshness in green lettuces (Neocleous et al., 2014; Parida \& Das, 2005).

The salinity of the root environment compromises plant development by reducing the osmotic potential of the solution, which is associated with the water stress caused by the difficulty to absorb water from the soil, accumulation of toxic ions in the tissues $\left(\mathrm{Cl}^{-}\right.$and $\left.\mathrm{Na}^{+}\right)$and ionic imbalance, leading to the reduction in the absorption of essential ions, such as $\mathrm{NO}_{3}{ }^{-}$and $\mathrm{Ca}^{2+}$ (Paulus et al., 2012; Soares et al., 2016; Cova et al., 2017). 
One alternative to minimize the effects of salinity is the enrichment of the root zone with nutrients, which increases plant tolerance to salinity by relieving the damagescaused by $\mathrm{Na}^{+}$and $\mathrm{Cl}^{-}$(Tzortzakis, 2009).

Calcium, in turn, is a constituent of the cell wall and acts in most processes of growth, development, maintenance and reproduction, being responsible for the mechanical resistance of vegetal structures, promotion of junction of cells and exoskeleton, besides controlling high turgor pressures and acting in the protection against physical and chemical injuries (Taiz \& Zeiger, 2013).

In addition, increment of $\mathrm{Ca}$ content in leaf tissues can increase photosynthetic capacity and also chlorophyll synthesis (Fallovo et al., 2009). Hence, using $\mathrm{Ca}$ in the nutrient solution can be one method to reduce some physiological imbalances due to salinity, such as the absorption of micro- and macroelements (Tzortzakis, 2009; Borghesi et al., 2013).

In this context, the present study aimed to evaluate the effect of calcium nitrate enrichment in saline nutrient solution on two lettuce cultivars grown in coconut fiber.

\section{Method}

The experiment was carried out from July to August 2017, in a greenhouse, in the experimental sector of the Department of Environmental and Technological Sciences of the Federal Rural University of the Semi-Arid

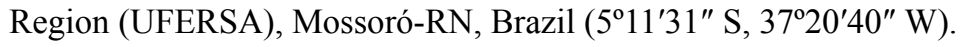

The greenhouse used in the study is $6.40 \mathrm{~m}$ wide and $22.5 \mathrm{~m}$ long, with an arched roof covered by 0.10 -mm-thick, transparent low-densitypolyethylene, treated against the action of ultraviolet rays. Sides and front walls are equipped with anti-aphid net and the 0.30 -m-high wall is made of reinforced concrete.

A completely randomized block design was used, in a $2 \times 5$ factorial scheme, with three replicates. Each replicate was formed by 4 plastic pots with capacity for $3.0 \mathrm{~L}$, containing coconut fiber and one plant each.

Treatments resulted from the combination of two lettuce cultivars ['Elba' (curly) and 'Irene' (crisphead)] with five nutrient solutions, being the nutritional solution standard following the recommendation of Furlani et al. (1999) and the others salinized with sodium chloride. The amounts of salts used in the preparation of nutrient solutions are shown in Table 1.

Table 1. Quantities of fertilizers, sodium chloride, and electrical conductivity of nutritive solutions

\begin{tabular}{|c|c|c|c|c|c|}
\hline \multirow{2}{*}{ Fertilizers } & \multicolumn{5}{|c|}{ Nutritive solutions } \\
\hline & $\mathrm{S} 1$ & $\mathrm{~S} 2$ & S3 & S4 & S5 \\
\hline & \multicolumn{5}{|c|}{ 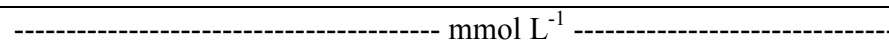 } \\
\hline Monoammonium fosfate & 1.30 & 1.30 & 1.30 & 1.30 & 1.30 \\
\hline Calcium nitrate & 4.57 & 4.57 & 6.86 & 9.15 & 11.43 \\
\hline Potassium nitrate & 4.95 & 4.95 & 4.95 & 4.95 & 4.95 \\
\hline Magnesium sulfate & 3.32 & 3.32 & 3.32 & 3.32 & 3.32 \\
\hline $\mathrm{NaCl}$ & 0 & 28.48 & 28.48 & 28.48 & 28.48 \\
\hline $\operatorname{Rexolin}^{(B)}\left(\mathrm{mg} \mathrm{L}^{-1}\right)$ & 30 & 30 & 30 & 30 & 30 \\
\hline $\left.\mathrm{CE}(\mathrm{dS} \mathrm{m})^{-1}\right)^{*}$ & 1.5 & $3.82 *$ & 4.35 & 4.84 & 5.03 \\
\hline
\end{tabular}

Note. ${ }^{*}$ electrical conductivity after preparation of nutritive solutions. Rexolin ${ }^{\circledR}$ : micronutrients $(11.6 \%$ of potassium oxide $\left(\mathrm{K}_{2} \mathrm{O}\right), 1.28 \%$ of sulfur $(\mathrm{S}), 0.86 \%$ of magnesium $(\mathrm{Mg}), 2.1 \%$ of boron $(\mathrm{B}), 2.66 \%$ of iron $(\mathrm{Fe})$, $0.36 \%$ of copper $(\mathrm{Cu}), 2.48 \%$ of manganese $(\mathrm{Mn}), 0.036 \%$ of molybdenum $(\mathrm{Mo})$, and $3.38 \%$ of zinc $(\mathrm{Zn})$.

Nutritive solutions were prepared using water from a deep water well at the university, with the following physicochemical characteristics: $\mathrm{pH}=8.97 ; \mathrm{ECw}=0.62 \mathrm{dS} \mathrm{m}^{-1} ; \mathrm{K}^{+}=2.07 \mathrm{mmol}_{\mathrm{c}} \mathrm{L}^{-1} ; \mathrm{Na}^{+}=0.91 \mathrm{mmol}_{\mathrm{c}} \mathrm{L}^{-1}$; $\mathrm{Ca}^{2+}=2.87 \mathrm{mmol}_{\mathrm{c}} \mathrm{L}^{-1} ; \mathrm{Mg}^{2+}=0.51 \mathrm{mmol}_{\mathrm{c}} \mathrm{L}^{-1} ; \mathrm{Cl}^{-}=3.91 \mathrm{mmol}_{\mathrm{c}} \mathrm{L}^{-1} ; \mathrm{CO}_{3}{ }^{2-}=0.23 \mathrm{mmol}_{\mathrm{c}} \mathrm{L}^{-1} ; \mathrm{HCO}_{3}^{-}=1.78$ $\operatorname{mmol}_{\mathrm{c}} \mathrm{L}^{-1} ; \mathrm{SAR}=0.91 \mathrm{mmol}_{\mathrm{c}} \mathrm{L}^{-1} ; \mathrm{SAR}=0.70\left(\mathrm{mmol}_{\mathrm{c}} \mathrm{L}^{-1}\right)^{0.5}$.

The $\mathrm{pH}$ of each solution was adjusted to 6.0-6.5 through the application of $0.1 \mathrm{~mol} \mathrm{~L}^{-1} \mathrm{KOH}$ or $\mathrm{HCl}$ solution. After the solutions were prepared, electrical conductivity was measured using a benchtop conductivity meter (TECNOPON mCA150), are shown in Table 1. 
Each nutrient solution was applied using a drip irrigation system composed of an electric pump, a plastic tank $(60 \mathrm{~L})$, lateral lines made of polyethylene hose $(16 \mathrm{~mm}$ diameter) and $40 \mathrm{~cm}$ long microtube drippers with flow rate of $2.5 \mathrm{~L} \mathrm{~h}^{-1}$.

Irrigation was controlled using digital timers programmed to perform different daily irrigation events, applying sufficient nutrient solution to meet crop water demand. The number of irrigation events and their duration varied along the cycle according to the crop requirement. In the first two weeks after transplantation, six irrigations were performed per day (7:00 a.m., 9:00 a.m.; 11:00 a.m., 01:00 p.m., 15:00 p.m., and 17:00 p.m.), lasting 1 minute each; in the last two weeks, eight irrigations were performed per day (7:00 a.m., 9:00 a.m.; 11:00 a.m., 12:00 a.m., 01:00 p.m., 02:00 p.m., 03:00 p.m. and 05:00 p.m.), lasting 1 minute and 30 seconds each.

Plants were harvested 30 days after transplantation and the following variables were analyzed: head diameter (HD), measured using a graduated ruler, considering the average diameter of two perpendicular means, expressed in $\mathrm{cm}$; stem diameter (SD), determined using a digital caliper in the region close to the substrate, expressed in $\mathrm{mm}$; number of leaves (NL), determined by counting only leaves with commercial standard (not considering leaves less than three $\mathrm{cm}$ in length, dried and/or damaged); fresh weight aerial part (FW), obtained by weighing the plants on precision scale $(0.01 \mathrm{~g})$; dry weight (DW), determined after plants were dried in forced-air oven at temperature of $65^{\circ} \mathrm{C}$, until constant weight.

Besides these variables, leaf area (LA), specific leaf area (SLA) and leaf succulence (LS) were also determined. Leaf area was determined through the leaf disc method, using a volumetric ring with internal diameter of $2.5 \mathrm{~cm}$ $\left(4.9 \mathrm{~cm}^{2}\right)$ to collect 20 leaf discs per plot. The leaf discs were placed in paper bags and dried in forced-air oven at temperature of $65^{\circ} \mathrm{C}$ until constant weight. Leaf disc area and dry weight values were used to determine the leaf area of the plant, according to Equation 1.

$$
\mathrm{LA}=\frac{\mathrm{DA} \times \mathrm{LDW}}{\mathrm{DDW} / \mathrm{N}}
$$

Where, LA: leaf area, $\mathrm{cm}^{2}$; DA: leaf disc area, $\mathrm{cm}^{2}$; LDW: leaf dry weight, g; DDW:leaf disc dry weight, g; N: number of discs used in the plot.

Specific leaf area was determined by the ratio between leaf area and leaf dry weight Equation 2.

$$
\mathrm{SLA}=\frac{\mathrm{LA}}{\mathrm{LDW}}
$$

Where, SLA: specific leaf area, $\mathrm{cm}^{2} \mathrm{~g}^{-1}$; LA:eaf area, $\mathrm{cm}^{2}$; LDW: leaf dry weight, $\mathrm{g}$.

Leaf succulence was determined through the ratio between leaf water content and leaf area, Equation 3.

$$
\mathrm{LS}=\frac{(\mathrm{LFW}-\mathrm{LDW})}{\mathrm{LA}}
$$

Where, LS: leaf succulence, $\mathrm{g} \mathrm{H}_{2} \mathrm{O} \mathrm{cm}^{-2}$; LFW: leaf fresh weight, g; LDW: leaf dry weight, g; LA: leaf area, $\mathrm{cm}^{2}$ plant $^{-1}$.

The obtained data were subjected to analysis of variance, and follow-up analyses were performed for variables that showed significant response to the interaction between factors. Means were compared by Tukey test at 0.05 probability level. The statistical analyses were performed using the program SISVAR (Ferreira, 2011).

\section{Results and Discussion}

The cultivars differed for head diameter (HD) only in the saline nutrient solution (S2), in which the cv. Irene surpassed the cv. Elba by 39.75\% (Figure 1A). Additionally, nutrient solutions had no effect on this variable in the cv. Irene. On the other hand, the use of saline water to prepare the nutrient solution reduced HD by $38.83 \%$ in the cv. Elba, but nutrient solution enrichment with calcium nitrate inhibited the deleterious effect of salinity on this variable (Figure 1A). 

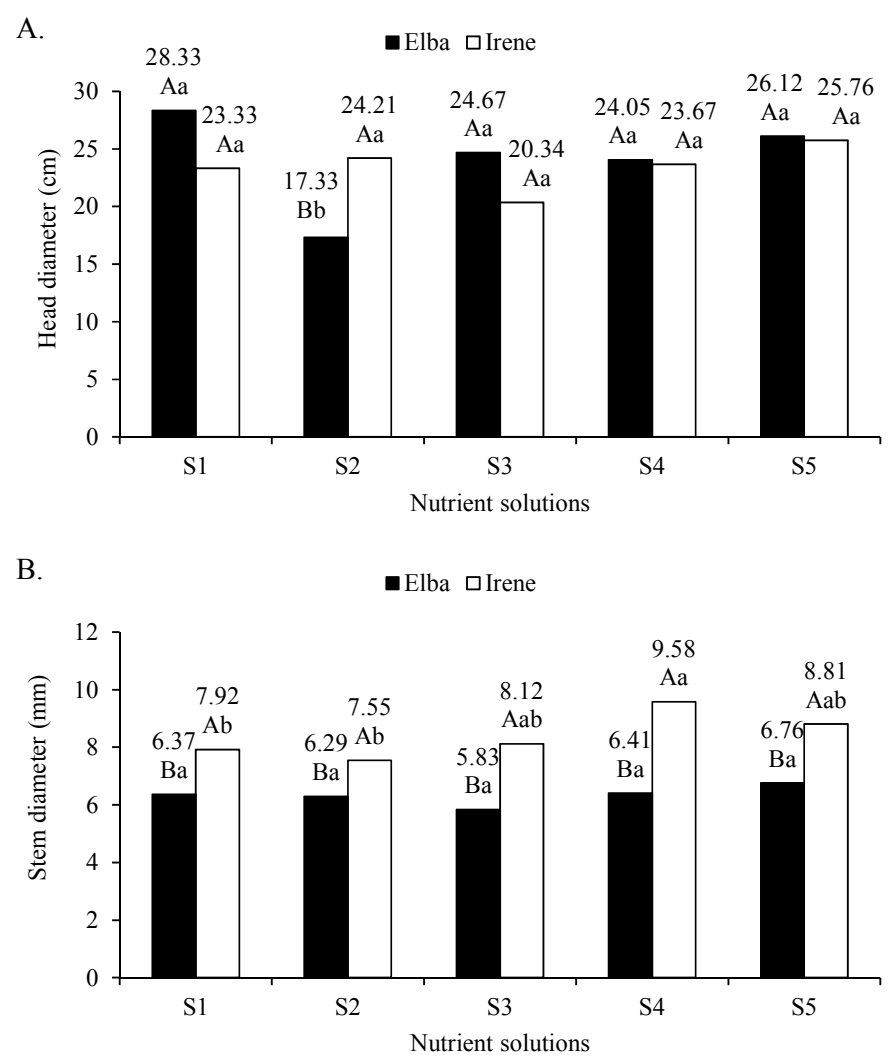

Figure 1. Head diameter (A) and stem diameter (B) of lettuce cultivars produced in coconut fiber and fertigated with saline nutrient solutions enriched with calcium nitrate (Means followed by the same letters, uppercase for cultivars and lowercase for nutrient solutions, do not differ by Tukey test at 0.05 probability level). [S1: standard nutrient solution; $\mathrm{S} 2: \mathrm{S} 1+\mathrm{NaCl}\left(28.48 \mathrm{mmol} \mathrm{L}^{-1}\right) ; \mathrm{S} 3: \mathrm{S} 2+\mathrm{Ca}\left(\mathrm{NO}_{3}\right)_{2}\left(6.89 \mathrm{mmol} \mathrm{L}^{-1}\right) ; \mathrm{S} 4: \mathrm{S} 2+\mathrm{Ca}\left(\mathrm{NO}_{3}\right)_{2}(9.15$ mmol L-1 $)$ : S5: $\left.\mathrm{S} 2+\mathrm{Ca}\left(\mathrm{NO}_{3}\right)_{2}\left(11.43 \mathrm{mmol} \mathrm{L}^{-1}\right)\right]$

Negative effect of salinity on lettuce head diameter has also been found by other authors, such as Santos et al. (2010). Guimarães et al. (2016), working with seven lettuce cultivars, observed that the effect of salinity on this variable varied according to the cultivar.

Stem diameter (SD) was significantly different between the cultivars. The cv. Irene was superior to the cv. Elba in all nutrient solutions, with greatest differences in the solutions S4 (49.45\%) and S3 (39.28\%), whereas the lowest difference occurred in the solution S2 (20.03\%). The nutrient solutions caused no significant response on $\mathrm{SD}$ in the cv. Elba, leading to mean value of $6.33 \mathrm{~mm}$. On the other hand, the cv. Irene showed significant response to the treatments, with higher values in the solutions S3, S4 and S5, which indicates that it may have higher Ca demand compared with the cv. Elba (Figure 1B).

According to Mota et al. (2001), stem diameter is a characteristic of great importance for the fast food industry, because the stem is manually removed for subsequent slicing of the lettuce head. Therefore, the thicker the stem, the faster it is removed, increasing industrial yield. 
A.
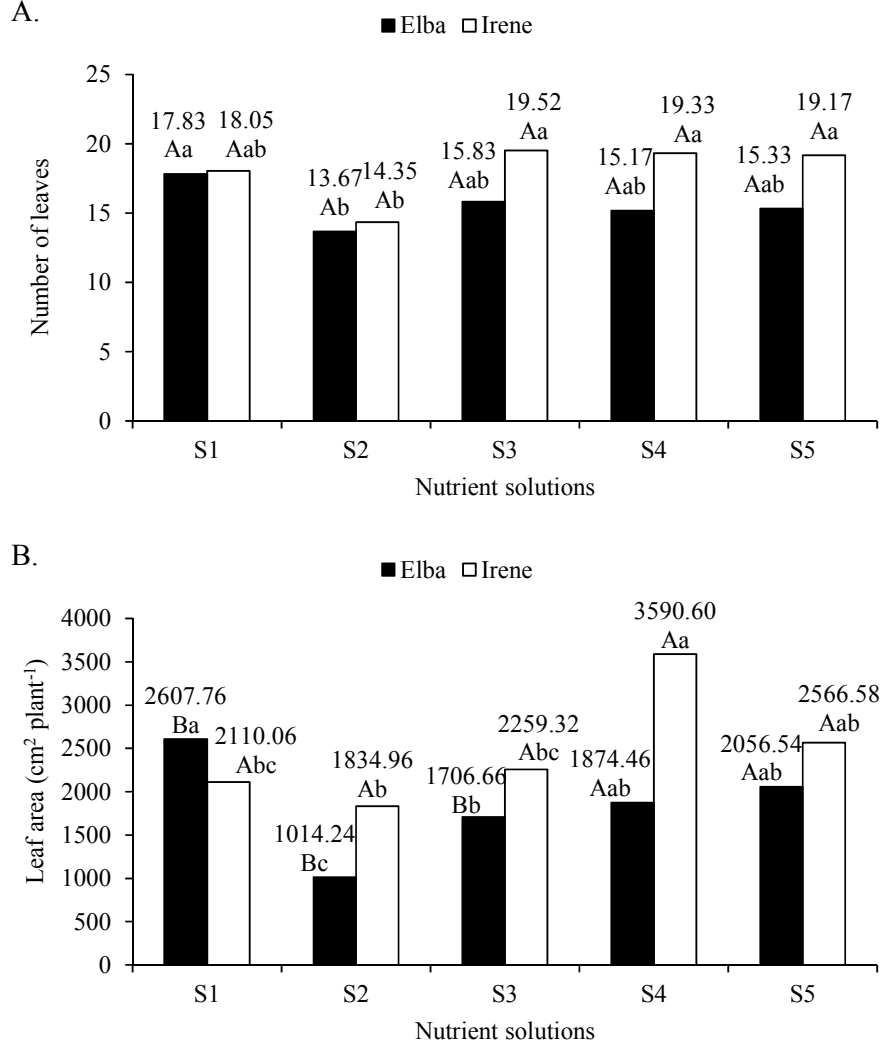

Figure 2. Number of leaves (A) and leaf area (B) of lettuce cultivars produced in coconut fiber and fertigated with saline nutrient solutions enriched with calcium nitrate (Means followed by the same letters, uppercase for cultivars and lowercase for nutrient solutions, do not differ by Tukey test at 0.05 probability level). [S1: standard nutrient solution; $\mathrm{S} 2: \mathrm{S} 1+\mathrm{NaCl}\left(28.48 \mathrm{mmol} \mathrm{L}^{-1}\right)$; $\mathrm{S} 3: \mathrm{S} 2+\mathrm{Ca}\left(\mathrm{NO}_{3}\right)_{2}\left(6.89 \mathrm{mmol} \mathrm{L}^{-1}\right)$; S4: $\mathrm{S} 2+\mathrm{Ca}\left(\mathrm{NO}_{3}\right)_{2}(9.15$ mmol L $\left.\left.{ }^{-1}\right) ; \mathrm{S} 5: \mathrm{S} 2+\mathrm{Ca}\left(\mathrm{NO}_{3}\right)_{2}\left(11.43 \mathrm{mmol} \mathrm{L}^{-1}\right)\right]$

Regarding the number of leaves, except for the solutions S1 and S2, in which there was no difference between the cultivars, the cv. Irene was superior to the cv. Elba in all other nutrient solutions. Such superiority was equal to $23.3,27.4$ and $25.0 \%$, in the solutions S3, S4 and S5, respectively (Figure 2A).

Both cultivars showed reduction in the number of leaves when fertigated with saline nutrient solution (S2), with losses of 23.33 and $20.49 \%$ in the cv. Elba and Irene, respectively (Figure 2A). However, both cultivars exhibited positive responses to the enrichment of the saline nutrient solutions with $\mathrm{Ca}\left(\mathrm{NO}_{3}\right)_{2}$.

Leaf area (LA) was $19.08 \%$ higher in the cv. Elba in comparison to the cv. Irene when both were fertigated with $\mathrm{S} 1$. On the other hand, the cv. Irene was superior in the other nutrient solutions, with largest difference between the cultivars in the solutions S2 (80.92\%) and S4 (91.55\%). The use of saline nutrient solution (S2) reduced LA in both cultivars, causing losses of 61.11 and 13.04\% in Elba and Irene, respectively (Figure 2B).

Still referring to the variable LA, the extra addition of $\mathrm{Ca}\left(\mathrm{NO}_{3}\right)_{2}$ reduced the deleterious effect of salt stress on both cultivars, with more expressive effect on the cv. Irene, in which the solutions enriched with $\mathrm{Ca}\left(\mathrm{NO}_{3}\right)_{2}$ led to higher LA compared with the standard nutrient solution (S1), especially S4, which was superior to S1 by $70.16 \%$ (Figure 2B).

The cultivars did not differ for the variable fresh weight in the standard nutrient solution, but differed in the other nutrient solutions, with superiority of the cv. Irene, especially in S3 and S4, in which its fresh weight was 110.25 and $163.81 \%$ higher compared with the cv. Elba, respectively (Figure 3A). 

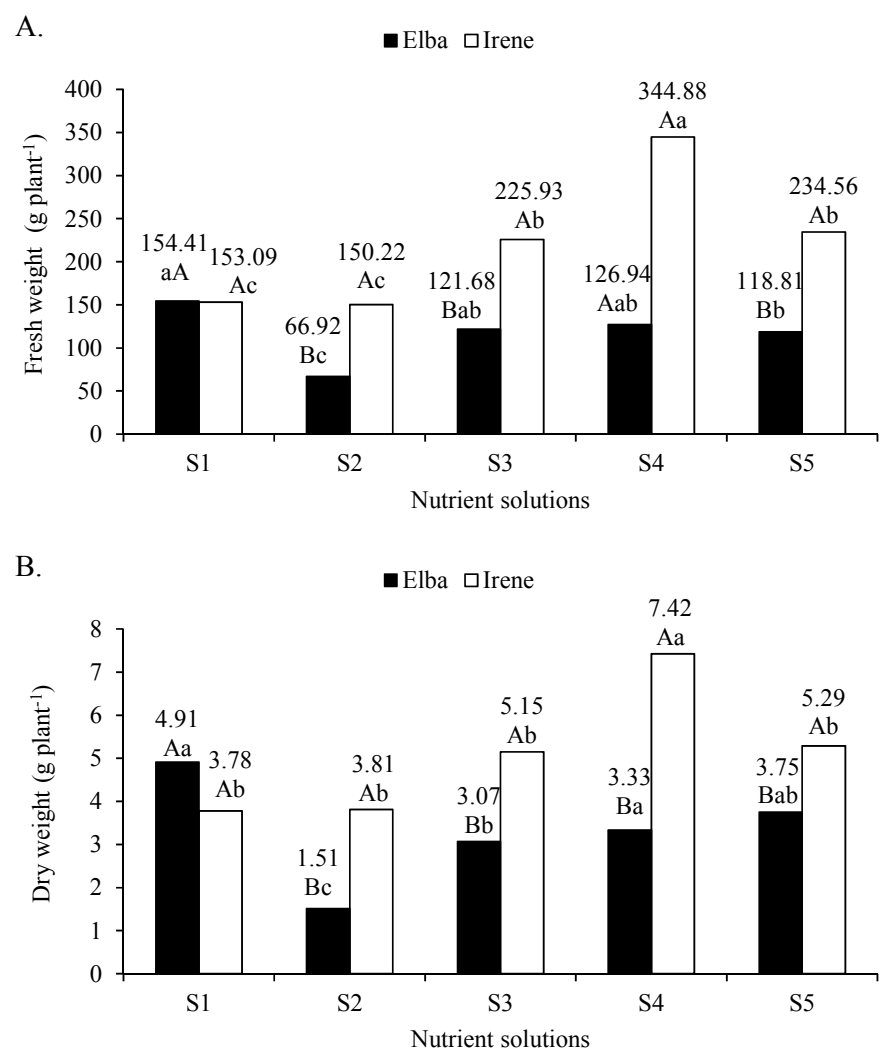

Figure 3. Fresh weight (A) and dry weight (B) of lettuce cultivars produced in coconut fiber and fertigated with saline nutrient solutions enriched with calcium nitrate (Means followed by the same letters, uppercase for cultivars and lowercase for nutrient solutions, do not differ by Tukey test at 0.05 probability level). [S1: standard nutrient solution; $\mathrm{S} 2: \mathrm{S} 1+\mathrm{NaCl}\left(28.48 \mathrm{mmol} \mathrm{L}^{-1}\right) ; \mathrm{S} 3: \mathrm{S} 2+\mathrm{Ca}\left(\mathrm{NO}_{3}\right)_{2}\left(6.89 \mathrm{mmol} \mathrm{L}^{-1}\right) ; \mathrm{S} 4: \mathrm{S} 2+\mathrm{Ca}\left(\mathrm{NO}_{3}\right)_{2}(9.15$ $\left.\mathrm{mmol} \mathrm{L}-1) ; \mathrm{S} 5: \mathrm{S} 2+\mathrm{Ca}\left(\mathrm{NO}_{3}\right)_{2}\left(11.43 \mathrm{mmol} \mathrm{L}^{-1}\right)\right]$

Both cultivars were affected by the salinity of nutrient solutions, but showed different responses. Fresh weight decreased in the cv. Elba when saline nutrient solution (S2) was used, with loss of 56.66\% compared with the value obtained in the standard nutrient solution (S1). Additionally, it was observed that nutrient solution enrichment with $\mathrm{Ca}\left(\mathrm{NO}_{3}\right)_{2}$ reduced the deleterious effect of salinity. For the cv. Irene, salinity had no significant effect on fresh weight (S2) and there was a positive response to the extra application of $\mathrm{Ca}\left(\mathrm{NO}_{3}\right)_{2}$. Highest values were obtained in the solutions S3, S4 and S5, which were respectively $67.11,118.75$ and $53.22 \%$ higher than the fresh weight obtained in the standard nutrient solution (Figure 3A).

Positive effect of $\mathrm{Ca}$ supplementation on fresh weight production has been found by other authors, working with other vegetables such as chicory (Tzortzakis, 2010) and spinach (Turhan et al., 2013). In addition, attention should also be paid to the increase of nitrogen concentration in the nutrient solution, due to competition in the absorption between nitrate and chloride, so that an increase in the nitrate concentration in the root zone can inhibit a greater uptake of chloride by the plant.

As observed for the variable fresh weight, there was also no significant difference in dry weight (DW) between the cultivars when fertigated with the standard nutrient solution (S1). However, in the other nutrient solutions, the cv. Irene was superior to the cv. Elba, especially in S2 and S4, in which its DW was 152.32 and $122.82 \%$ higher, respectively (Figure 3B).

Regarding the effect of the nutrient solutions on DW, the saline nutrient solution (S2) caused reduction of DW only in the cv. Elba, equal to $69.25 \%$ in comparison to the DW obtained in the solution S1. In addition, nutrient solution enrichment with $\mathrm{Ca}\left(\mathrm{NO}_{3}\right)_{2}$ reduced the effect of salinity, although there were losses of $37.47 \%(\mathrm{~S} 3)$, $32.18 \%$ (S4) and $23.62 \%$ (S5). For the cv. Irene, there was no significant response to the addition of $\mathrm{NaCl}$ in the nutrient solution (S2). Moreover, this cultivar showed positive response to the extra addition of $\mathrm{Ca}\left(\mathrm{NO}_{3}\right)_{2}$, with increments of 36.24, 96.29 and 39.95\% in the solutions S3, S4 and S5, respectively (Figure 3B). 
These data demonstrate that the cv. Irene is more tolerant to nutrient solution salinity and has higher demand for $\mathrm{Ca}\left(\mathrm{NO}_{3}\right)_{2}$ to obtain maximum biomass production. Other authors have already observed that the cv. Elba is sensitive to salinity in hydroponic cultivation NFT (Santos et al., 2011).

Such reduction in plant growth due to salt stress can be explained by photosynthetic limitations, resulting from stomatal closure and, simultaneously, lower $\mathrm{CO}_{2}$ assimilation (Taarit et al., 2010). In addition, it may be associated with the energetic expenditure involved in the synthesis of organic solutes, necessary for the processes of compartmentalization and regulation of the transport of ions (Mendonça et al., 2007).

The cultivars did not differ significantly for the variable leaf succulence (LS) in the standard nutrient solution. The cv. Irene was superior to the cv. Elba in the other solutions, especially in S3 (50.78\%). In addition, the solutions had no effect on the LS of the cv. Elba, which showed mean value of $0.06 \mathrm{~g} \mathrm{H}_{2} \mathrm{O} \mathrm{cm}^{-2}$ of leaf. On the other hand, the use of saline nutrient solution increased LS in the cv. Irene (Figure 4A).
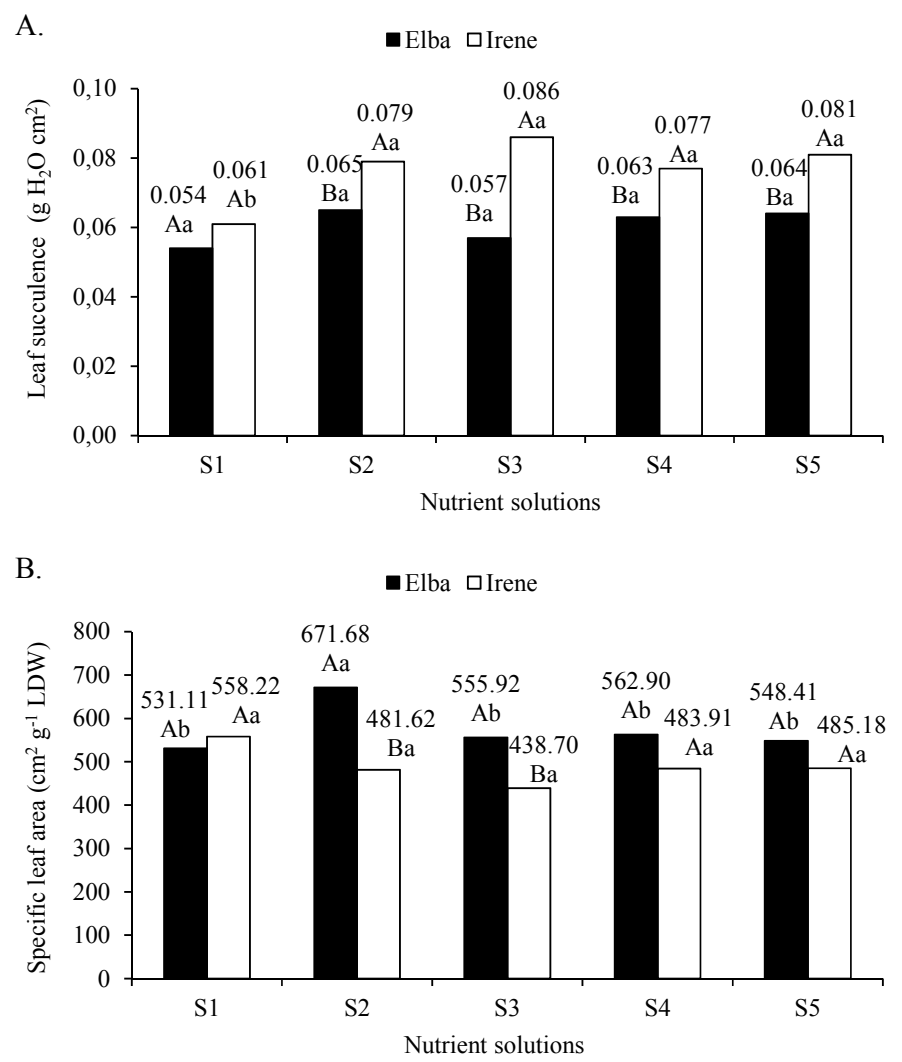

Figure 4. Leaf succulence (A) and specific leaf area (B) of lettuce cultivars produced in coconut fiber and fertigated with saline nutrient solutions enriched with calcium nitrate (Means followed by the same letters, uppercase for cultivars and lowercase for nutrient solutions, do not differ by Tukey test at 0.05 probability level). [S1: standard nutrient solution; $\mathrm{S} 2: \mathrm{S} 1+\mathrm{NaCl}\left(28.48 \mathrm{mmol} \mathrm{L}^{-1}\right) ; \mathrm{S} 3: \mathrm{S} 2+\mathrm{Ca}\left(\mathrm{NO}_{3}\right)_{2}\left(6.89 \mathrm{mmol} \mathrm{L}^{-1}\right) ; \mathrm{S} 4: \mathrm{S} 2+$ $\left.\mathrm{Ca}\left(\mathrm{NO}_{3}\right)_{2}\left(9.15 \mathrm{mmol} \mathrm{L}^{-1}\right) ; \mathrm{S} 5: \mathrm{S} 2+\mathrm{Ca}\left(\mathrm{NO}_{3}\right)_{2}\left(11.43 \mathrm{mmol} \mathrm{L}^{-1}\right)\right]$

Succulence is a characteristic with important anatomical and physiological implications in stressed plants and is directly related to the accumulation of salts in the tissues (Aquino et al., 2007). Leaf succulence allows the regulation of the concentration of salts in the leaf tissues and directly depends on the absorption, transport and accumulation of ions, possibly contributing to reducing the effect of salts on plant growth (Larcher, 2000).

The cv. Elba showed higher specific leaf area (SLA) in the solutions S2 and S3, being higher in 28.29 and $21.08 \%$, respectively (Figure 4B). Figure 4B also shows that the cultivars responded differently to the addition of $\mathrm{NaCl}$ in the nutrient solution; SLA increased in the cv. Elba in S2, but did not affect SLA in the cv. Irene

SLA represents the ratio between leaf area and leaf dry weight. Hence, plants with lower SLA exhibit thicker leaves. In some plants subjected to salt stress conditions, leaf mesophyll thickness increases due to the increment in the number and length of palisade cells and in the number of palisade and spongy cell layers (Parida et al., 
2004). According to Ottow et al. (2005), such increase in leaf succulence is due to the increment in the number and volume of the cells, thus causing a dilution in the leaf contents of sodium and chloride. Hence, it is considered as an acclimatization to the saline environment.

Since $\mathrm{Ca}\left(\mathrm{NO}_{3}\right)_{2}$ contains in its composition very similar contents of $\mathrm{Ca}$ and $\mathrm{N}(19 \%$ of $\mathrm{Ca}$ and $15.5 \%$ of $\mathrm{N})$, it is not possible to separate the individual effect of these nutrients. Therefore, plant response was attributed to their joint effect. Nitrogen is a macronutrient found in organic compounds such as amino acids and nucleic acids, and participates in various physiological processes in the plant life cycle, such as ionic absorption, photosynthesis, respiration and cell multiplication and differentiation (Malavolta, 2006).

Due to the importance of $\mathrm{Ca}$ and $\mathrm{N}$ for plant development, some authors found that their deficiency leads to significant reduction in lettuce growth (Almeida et al., 2011; Tischer \& Siqueira Neto, 2012). The positive effect of saline nutrient solution enrichment with $\mathrm{Ca}\left(\mathrm{NO}_{3}\right)_{2}$ is due to the probable increment of $\mathrm{Ca}^{2+}$ and $\mathrm{NO}_{3}{ }_{3}$ contents in the lettuce leaf tissue, since the excess of $\mathrm{Na}^{+}$and $\mathrm{Cl}^{-}$ions in the leaf tissue, resulting from the $\mathrm{NaCl}$ addition in the nutrient solution, causes reduction in the leaf contents of $\mathrm{Ca}^{2+}$ and $\mathrm{NO}_{3}{ }^{-}$(Paulus et al., 2012; Soares et al., 2016; Cova et al., 2017).

\section{Conclusion}

The cv. Irene (Crisphead) is more tolerant to nutrient solution salinity compared with the cv. Elba (Curly).

Nutrient solutions enriched with 50 and $100 \%$ of $\mathrm{Ca}\left(\mathrm{NO}_{3}\right)_{2}$ promoted better performance of the cultivars Elba and Irene, respectively, fertigated with saline nutrient solution.

\section{References}

Almeida, T. B. F., Prado, R. M., Correia, M. A. R., Puga, A. P., \& Barbosa, J. C. (2011). Avaliação nutricional da alface cultivada em soluções nutritivas suprimidas de macronutrientes. Revista Biotemas, 24, 27-36.

Aquino, A. J. S., Lacerda, C. F., Bezerra, M. A., Gomes Filho, E., \& Costa, R. N. T. (2007). Crescimento, partição de matéria seca e retenção de $\mathrm{Na}^{+}, \mathrm{K}^{+} \mathrm{e} \mathrm{Cl}^{-}$em dois genótipos de sorgo irrigados com águas salinas. Revista Brasileira de Ciência do Solo, 31, 961-971. https://doi.org/10.1590/S0100-06832007000500013

Borghesi, E., Carmassi, G., Uguccioni, M. C., Vernieri, P., \& Malorgio, F. (2013). Effects of calcium and salinity stress on quality of lettuce in soilless culture. Journal of Plant Nutrition, 36, 677-690. https://doi.org/ $10.1080 / 01904167.2012 .721909$

Cova, A. M. W., Freitas, F. T. O., Viana, P. C., Rafael, M. R. S., Azevdo Neto, A. D., \& Soares, T. M. (2017). Content of inorganic solutes in lettuce grown with brackish water in different hydroponic systems. Revista Brasileira de Engenharia Agrícola e Ambiental, 21, 150-155. https://doi.org/10.1590/1807-1929/ agriambi.v21n3p150-155

Fallovo, C., Rouphael, Y., Cardarelli, M., Rea, E., Battistelli, A., \& Colla, G. (2009). Yield and quality of leafy lettuce in response to nutrient solution composition and growing season. Journal of Food Agriculture and Environment, 7, 456-462.

Ferreira, D. F. (2011). Sisvar: a computer statistical analysis system. Ciência \& Agrotecnologia, 35(6), 1039-1042. https://doi.org/10.1590/S1413-70542011000600001

Flowers, T. J., \& Flowers, S. A. (2005). Why does salinity pose such a difficult problem for plant breeders? Agricultural Water Management, 78, 15-24. https://doi.org/10.1016/j.agwat.2005.04.015

Furlani, P. R., Silveira, L. C. P., Bolonhezi, D., \& Faquin, V. (1999). Cultivo hidropônico de plantas (p. 52, Boletim Técnico, 180). Campinas: IAC.

Guimarães, I. P., Oliveira, F. A., Torres, S. B., Pereira, F. E. C. B., França, F. D., \& Oliveira, M. K. T. (2016). Use of fish-farming wastewater in lettuce cultivation. Revista Brasileira de Engenharia Agrícola e Ambiental, 20, 728-733. https://doi.org/10.1590/1807-1929/agriambi.v20n8p728-733

Larcher, W. (2000). Ecofisiologia vegetal (p. 533). São Carlos, RiMa.

Luz, G. L., Medeiros, S. L. P., Manfron, P. A., Amaral, A. D., Müller, L., Torres, M. G., \& Mentges, L. (2008). A questão do nitrato em alface hidropônica e a saúde humana. Ciência Rural, 38, 2388-2394. https://doi.org/10.1590/S0103-84782008000800049

Malavolta, E. (2006). Manual de nutrição mineral de plantas (p. 638). São Paulo: Editora Agronômica Ceres. 
Mendonça, A. V. R., Carneiro, J. G. A., Barroso, D. G., Santiago, A. R., Rodrigues, L. A., \& Freitas, T. A. S. (2007). Características biométricas de mudas de eucalyptus sp sob estresse salino. Revista Árvore, 31, 365-372. https://doi.org/10.1590/S0100-67622007000300001

Mota, J. H., Souza, R. J. S., Silva, E. C., Carvalho, J. G., \& Yuri, J. E. (2001). Efeito do cloreto de potássio via fertirrigação na produção de alface-americana em cultivo protegido. Ciência e Agrotecnologia, 25, 542-549.

Munns, R. (2005). Genes and salt tolerance: Bring them together. New Phytologist, 167, 645-663. https://doi.org/ 10.1111/j.1469-8137.2005.01487.x

Neocleous, D., Koukounaras, A., Siomos, A. S., \& Vasilakakis, M. (2014). Changes in photosynthesis, yield, and quality of baby lettuce under salinity stress. Journal of Agricultural Science and Technology, 16, 1335-1343.

Ottow, E. A., Brinker, M., Teichmann, T., Fritz, E., Kaiser, W., Brosche, M., ... Polle, A. (2005). Populuseuphratica displays apoplastic sodium accumulation, osmotic adjustment by decreases in calcium and soluble carbohydrates, and develops leaf succulence under salt stress. Plant Physiology, 139, 1762-1772. https://doi.org/10.1104/pp.105.069971

Parida, A. K., \& Das, A. B. (2005). Salt tolerance and salinity effects on plants: A review. Ecotoxicology and Environmental Safety, 60, 324-349. https://doi.org/10.1016/j.ecoenv.2004.06.010

Parida, A. K., Das, A. B., \& Mittra, B. (2004). Effects of salt on growth, ion accumulation, photosynthesis and leaf anatomy of the mangrove, Bruguiera parviflora. Trees, 18, 167-174. https://doi.org/10.1007/ s00468-003-0293-8

Paulus, D.; Paulus, E.; Nava, G. A., \& Moura, C. A. (2012). Crescimento, consumo hídrico e composição mineral de alface cultivada em hidroponia com águas salinas. Revista Ceres, 59, 110-117. https://doi.org/ $10.1590 / \mathrm{S} 0034-737 \mathrm{X} 2012000100016$

Sala, F. C., \& Costa, C. P. (2012). Retrospectiva e tendência da alfacicultura brasileira. Horticultura Brasileira, 30, 187-194. https://doi.org/10.1590/S0102-05362012000200002

Santos, A. N., Silva, E. F. F., Soares, T. M., Dantas, R. M. L., \& Silva, M. M. (2011). Produção de alface em NFT e Floating aproveitando água salobra e o rejeito da dessalinização. Revista Ciência Agronômica, 42, 319-326. https://doi.org/10.1590/S1806-66902011000200009

Santos, A. N., Soares, T. M., Silva, E. F. F., Silva, D. J. R., \& Montenegro, A. A. A. (2010). Cultivo hidropônico de alface com água salobra subterrânea e rejeito da dessalinização em Ibimirim, PE. Revista Brasileira de Engenharia Agricola e Ambiental, 14, 961-969. https://doi.org/10.1590/S1415-43662010000900008

Soares, H. R., Silva, E. F. F., Silva, G. F., Lira, R. M., \& Bezerra, R. R. (2016). Mineral nutrition of crisphead lettuce grown in a hydroponic system with brackish water. Revista Caatinga, 29, 656-664. https://doi.org/ $10.1590 / 1983-21252016 \mathrm{v} 29 \mathrm{n} 316 \mathrm{rc}$

Taarit, M. B., Msaada, K., Hosni, K., \& Marzouk, B. (2010). Changes in fatty acid and essential oil composition of sage (Salvia officinalis L.) leaves under $\mathrm{NaCl}$ stress. Food Chemistry, 119, 951-956. https://doi.org/ 10.1016/j.foodchem.2009.07.055

Taiz, L., \& Zeiger, E. (2013). Fisiologia vegetal (5th ed., p. 954). Porto Alegre: Artemed.

Tischer, J. C., \& Siqueira Neto, M. (2012). Avaliação da deficiência de macronutrientes em alface crespa. Ensaios e Ciência: Ciências Biológicas, Agrárias e da Saúde, 16, 43-57.

Turhan, A., Kuscu, H., Ozmen, N., Asi, B. B., Serbeci, M. S., \& Seniz, V. (2013). Alleviation of deleterious effects of salt stress byapplications of supplementary potassium-calciumon spinach. Acta Agriculturae Scandinavica, Section B - Soil \& Plant Science, 63, 184-192.

Tzortzakis, N. G. (2009). Influence of $\mathrm{NaCl}$ and calcium foliar spray on lettuce and endive growth using nutrient film technique. International Journal of Vegetable Science, 15, 1-13.

Tzortzakis, N. G. (2010). Potassium and calcium enrichment alleviatesalinity-induced stress in hydroponically grown endives. Horticultural Science, 37, 155-162. https://doi.org/10.17221/1/2010-HORTSCI 


\section{Copyrights}

Copyright for this article is retained by the author(s), with first publication rights granted to the journal.

This is an open-access article distributed under the terms and conditions of the Creative Commons Attribution license (http://creativecommons.org/licenses/by/4.0/). 